\title{
Analysis of financial indicators used to assess the sustainability of companies
}

\author{
Temirkhan Mukhambetov, Farida Yerdavletova*, Karlygash Kurbanova, Zhanar \\ Mukhametzhanova, and Kamilla Sadvakassova \\ Al-Farabi Kazakh National University, al-Farabiave., 71, 050040 Almaty, Kazakhstan
}

\begin{abstract}
The authors present a methodology for using financial indicators to assess the value of companies. The article is dedicated to a comprehensive research of EBITDA. As a research objective, the authors identified an attempt to solve the problem of companies'comparability with identical proportions of financial results, the possibility of identifying the most financially stable companies. Based on the analysis of various interpretations, applying of this indicator in different directions is considered. As a component of various coefficients that characterize the company's financial stability, it's recommended to use the EBITDA indicator. The behooves and opportunities that open up when using it are revealed. The research shows to the need to apply this indicator, because this coefficient is able to more fully reveal the stability of the company, by increasing the amount of real profit, the amount of which is limited due to the presence of a large share of non-cash expenses in companies. In the process of research, such general scientific methods as monitoring, comparison, description, systematic and analytical approach, comparative analysis, scientific abstraction, expert assessment, analysis of reasons and consequences were used.
\end{abstract}

\section{Introduction}

Sustainable economic development is based on the sustainable development of enterprises that form the basis of the economy.

At the same time, the problem of assessing the sustainable development of an enterprise naturally arises. In our opinion, EBIT and EBITDA indicators can be widely used in terms of financial stability of companies [1].

In practice, both EBIT and EBITDA are widely used, primarily by analysts and investors who use these indicators both to assess the financial position of companies and to determine their value. The initial purpose of these indicators is to assess the attractiveness (financial stability) of a particular company in terms of its absorption with borrowed funds.

Today, the EBITDA indicator is the third in a number of instrumentsfor evaluating the performance of the 500 largest US corporations and is included in their annual financial statements [2]. It shows the total profit that the company will receive in the current

* Corresponding author: vip.erdavletova@mail.ru 
reporting period. In addition, it is used to calculate the EBITDA ROI. This indicator provides an assessment of the company's operating results and is equated to operating cash flow, i.e. the cash that the company earned in the reporting period. While EBITDA, as the name implies, shows the company's financial results excluding the effect of capital structure (by excluding remuneration for borrowed funds), tax rates, and the influence of its depreciation policy. In this form, EBITDA allows, as a first approximation, to assess the cash flow, but excluding such a "non-cash" expense item as depreciation. In other words, the company's ability to earn money is evaluated regardless of whether it has debts to creditors, the state and the depreciation method used, that is, the profitability of its main activity is determined directly, which allows it to be analyzed "unbiased". This approach and this indicator become useful when comparing companies in the same industry, but which have different capital structures.

EBITDA is also widely used as a component of various coefficients that characterize the company's financial performance. The most well-known are the ratio of EVA/EBITDA, return on sales, etc. Investors use this indicator when they want to assess the expected return on their investments, that is, in order to assess the company's ability to cover its liabilities. The most important interest of an investor is the future income of the company in which he plans to invest, which means that the measure of EBITDA is important to him. For investors, this indicator is an important indicator of their return on investment.

\section{Methods and areas for using EBITDA}

The attention of many business analysts to the EBITDA indicator has been intensified recently. We'll look at some of them.

Lie and Lie (2002), exploring various practices used by specialists to assess the company's sustainability, make several conclusions, including the role of EBITDA.First, the authors argue that the asset multiple (market value to book value of assets) generally generates more precise and less biased estimates than do the sales and the earnings multiples. Second, although adjusting for companies' cash levels does not improve estimates of company value, using forecasted earnings rather than trailing earnings does. Third, the earnings before interest, taxes, depreciation, and amortization (EBITDA) multiple generally yields better estimates than does the EBIT multiple. Finally, the accuracy and bias of value estimates, and the relative performance of the multiples, vary greatly by company size, company profitability, and the extent of intangible value in the company [3].

Oliveira et al. (2017) studied the interrelation between effectiveness indicators and market value. Based on the analysis of 5 effectiveness variables (ROA, ROE, net margin, EBITDA and EBITDA margin) for the period from 2009 to 2014 using Pearson correlation and multiple linear regressions with panel data, 88 companies registered on the BM\&FBovespa exchange were researched. The results evidence that net margin, EBITDA, and EBITDA margin, in general, are the most influential indicators on the market value of the companies explored, while ROA and ROE are not related to the formation of the company's share price. According to the authors, there is also evidence of differences in the value of indicators for the market value of companies depending on the relevant economic sector [4].

Another research related to the BM \& F Bovespa stock exchange assesses the relevance of accounting information related to equity capital, net income and EBITDA in the process of forming the share price during the initial public offering of shares for the period between 2004 and 2012.Andrade and Lucena (2017) define regressions using the market value of companies (obtained by multiplying the number of shares by the market value of those shares at the IPO date) as dependent variables and accounting variables as independent or 
explanatory variables. The authors argue that among the surveyed accounting variables, only one of them (EBITDA) was significant at the level of $10 \%$, if evaluated separately and with a control variable, showing that it contributes to the formation of the share price. Other variables - net income and equity capital - are not relevant for the Brazilian capital market [5].

If used correctly, EBITDA can be used for other purposes as well.

Discounted cash flow (DCF)-based target price forecasts have the highest target price accuracy (TPA) of 70 per cent, while book value-based forecasts have the lowest TPA of 51.1 per cent for buy recommendations in India, says Sayed (2015). However, despite, its superior performance, DCF is the least used valuation model as analysts prefer heuristicsdriven earnings before interest, taxes, depreciation and amortization (EBITDA) or earnings multiples to produce target price forecasts. A significant and negative relationship with promoter holding explains the underperformance of book value-based target price forecasts-promoters possibly provide analysts with inflated book values which eventually result in inflated target price forecasts and lower target price accuracy [6].

Climent-Serrano et al. (2018) recommend using EBITDA to assess the sustainability of audit firms, as an indicator that measures and confirms the quality of their service. The 2008 financial crisis has transformed the business environment. The number of audited firms has fallen considerably since the crisis, leading to a reduction in the cost of auditing services as a result of fierce competition among auditors. This drop in audit fees is of great concern for audited firms because it may be correlated with a fall in audit service quality. Such a fall in quality ultimately harms the prestige of audited firms and therefore negatively affects their profits. Based on an application of fuzzy-set qualitative comparative analysis (fsQCA), this paper analyzes the quality of audit services following a drop in the fees charged by auditors. The factors analyzed in the empirical study were audit fees, other fees charged by the auditor, and the inclusion of explanatory paragraphs, qualified opinions, and emphasis of matter in audit reports. The EBITDA of the audited firms was chosen as an indicator of the quality of the service. The results of the analysis reveal that the quality of the auditing service has remained steady despite the fall in audit fees, as confirmed by the fact that the EBITDA has evolved positively without being affected by the fall in fees [7].

Damijan (2018), examining the extent of corporate leverage and range of excessive debt of Slovenian firms during the recent financial crisis, notes that half of all firms (of those with some non-zero debt and at least one employee) are found to face an unsustainable debt-to-EBITDA leverage ratio beyond 4, accounting for almost $80 \%$ of total outstanding debt. Moreover, a good quarter of all firms experience debt-to-EBITDA ratios exceeding 10 and hold almost half of total aggregate net debt. We then examine how this financial distress affects firm performance in terms of productivity, employment, exports, investment and survival. We find that, while less important during the good times (pre-recession period), lack of firms' financial soundness during the period of financial distress becomes a critical factor constraining firm performance. The extent of financial leverage and ability to service the outstanding debt are shown to inhibit firms' productivity growth as well as the dynamics of exports, employment and investment. Micro and small firms are found to suffer relatively more than larger firms from high leverage in terms of export and employment performance during the recession period.[8].

De Carvalhoet al. (2016) researching the interrelation between innovation and sustainability based on financial efficiency analysis using EBITDA, ROE, and ROA indicators. Organizational resilience is defined as the ability and capacity of an organization to withstand unexpected changes, discontinuities and environmental risks. Innovation contributes to achieve resilience as it enables organizations to renew over time. Our aim in this article is to analyze the relationship between innovation and resilience from the financial performance analysis with EBITDA, ROE and ROA indicators. We investigated a 
total of 10 companies divided into two groups, where the first was a group of 5 open-capital companies listed in the ranking of the 50 most innovative companies in Brazil, and the second being a group of 5 open-capital companies not listed in the ranking. We performed an analysis in two stages: the first consisted in calculating the indexes selected in the four fiscal years - 2011, 2012, 2013 and 2014 - chosen by coinciding with a period after the 2008-2009 crisis; in the second stage, we compared the indexes of the two groups of companies in the four established periods. The results indicate that innovative companies are able to sustain higher financial results than those non-innovative companies. As a main contribution, our study provides a longitudinal comparative analysis, thus providing evidence on the financial performance of innovative enterprises. [9].

Kaznacheev, Kjurchiski, and Samoilova (2017) analyze the effect of company measure on their EBITDA, market capitalization, and total oil production. The dramatic fall in oil prices during 2014-2015 allows assessing the adaptability of different corporate models in the oil industry. This article presents a comparative analysis of financial and operational performance of vertically integrated international oil companies and US junior oil companies. The authors analyzed the impact of the companies' size on their EBITDA, market capitalization and total oil production. The analysis demonstrated that, despite all their advantages, vertically integrated international oil companies made somewhat larger reductions in EBITDA than junior oil companies. International majors were also affected by larger drops in capitalization. At the same time, junior companies managed to make significantly larger increases in oil production. Panel data analysis using the difference-indifferences statistical method showed a positive correlation between EBITDA under low prices and the fact that the company belongs to the category of oil juniors. The authors come to the conclusion that small and medium companies with a significant share of shale production have demonstrated a high capacity for adaptation. These companies partially compensated the drop in revenues from lower oil prices by implementing rapid cost cutting, increased oil recovery, and the ability to increase production rapidly. The experience of junior oil companies has an impact on international oil majors in the area of technological innovation, and in broader corporate reorganization and adaptation. Over the last several years, shale companies have in many ways become trendsetters for the entire oil industry. They have innovated not only exploration and production technologies, but also management techniques which allowed reducing costs and increasing efficiency at a time of lower oil prices [10].

Janekova et al. (2017) recommend applying the method of analyzing deviations in net present value (NPV) at the stage of realization of the assessed investment project, which focuses on EBITDA and is supplemented by indicating the reasons for deviations. The results of the research show that NPV deviations are mainly due to a decrease in the volume of production of both products and a decrease in variable costs per unit of product. According to the authors, the recommended measures lead to a decrease in the probability of deviations [11].

\section{Analysis and assessing the sustainability of companies based on EBITDA}

The "financial stability" criterion is always relevant and is considered one of the main characteristics of the company's financial condition [12]. EBITDA also characterizes the company's sustainability because it determines the company's ability to fulfill its loanliabilities. Often similar companies with the same amount of net profit can have a huge difference in the value(cost) of the company. Similarly, companies with similar interest rates may have significantly different levels of ability to make the necessary payments on 
their debt liabilities. We will consider the situation based on the conditional data shown in table 1 .

Table 3.Comparative financial Data of "Berlik" and "Search" companies as of December 31, 2019 (c.u.)

\begin{tabular}{|l|r|r|}
\hline \multicolumn{1}{|c|}{ Indicators } & \multicolumn{1}{c|}{ "Berlik" } & "Search" \\
\hline Totalamountofliabilities & 237,50 & 218,75 \\
\hline Equitycapital & 187,50 & 168,75 \\
\hline Totalcapital & 425,00 & 387,50 \\
\hline Incomefromsales & 500,00 & 437,50 \\
\hline Primecostofsales & 400,00 & 350,00 \\
\hline \multicolumn{1}{|c|}{ Depreciationandamortization } & 18,75 & 7,50 \\
\hline \multicolumn{1}{|c|}{ Generaladministrativeexpenses } & 28,75 & 32,50 \\
\hline Operatingprofit & 52,50 & 47,50 \\
\hline Remunerationexpenses & 20,00 & 22,50 \\
\hline Profitbeforetax & 27,50 & 25,00 \\
\hline Tax & 9,25 & 8,50 \\
\hline Netprofit & 18,25 & 16,50 \\
\hline
\end{tabular}

When evaluated on the basis of the usual fixed cost coverage coefficient according to formula, both companies wear equally risky, with multiplier coefficients of 2.10 times and 2.11 times, respectively.

The fixed cost coverage coefficient is calculated using the formula (1):

$$
\text { NetIncome + IncomeTaxes + InterestExpense }
$$

Then the coverage coefficientof expenses on remuneration for the use of borrowed funds will be:

"Berlik"company

$$
\frac{18,25+9,25+25,00}{25,00}=2,1
$$

“Search"company

$$
\frac{16,50+8,50+22,50}{22,50}=2,11
$$

For convenience, we will refer to this standard credit measure as an EBIT-based coverage coefficient. It should be noted that for some companies, the amount of net profit, income tax and remuneration expenses is not equivalent to EBIT, which reflects the presence of factors such as extraordinary items and the income of minority shareholders (ordinary shareholders) below the level of gross profit before tax.

As it happens, "Search" and "Berlik" are almost ideal for financial leverage, another standard measure of credit risk, which is calculated as the ratio of total debt to total capital using the formula (2):

$$
\frac{\text { TotalDebt }}{\text { TotalDebt+Equity }} * 100 \%
$$

The debt-to-equity capitalratio for the two companies was: 
"Berlik" company

$$
\frac{237,5}{237,5+187,5}=55,9 \%
$$

"Search" company

$$
\frac{218,75}{218,75+168,75}=56,45 \%
$$

According to these criteria, lending to "Search" company is as safe an offer as lending to "Berlik" company. However, the use of EBITDA in the analysis nevertheless shows that "Berlik" is more stable, as it will be better able to perform its remuneration liabilities in the event of a business crisis.

As can be seen from table 1, in the analyzed year, the profit from the sale of "Berlik" company, net of the cost of goods sold, is 100 million tenge. We assume that, due to a combination of reduced revenue and margin, this numeral is reduced by $40 \%$, that is, to 60 million tenge, while other operating expenses remain unchanged. At the date under review, operating profit is only 12.5 million tenge, which is only half of the remuneration expense of 25 million tenge. The remuneration expenses coverage coefficient is reduced to 0.50 , in contrast to the previously calculated value of 2.10 times.

However, "Berlik" will be able to pay remuneration for its debt. Because depreciation and amortization in the amount of 18.75 million tenge collected to profit are non-cash expenses. Adding these non-tax levies shows that the company is stable, as its interest is covered by a difference of 1.25 :

EBITDA Coverage Interest [2]

NetIncome + IncomeTaxes + InterestExpense + Depreciation + Amortization Interest expense

$$
\frac{(-8,25)+(-4,25)+25,0+18,75}{25,00}=1,25
$$

On the contrary, if we assume that "Search"company'sgross profit will decrease by $40 \%$, its percentage remuneration will be 0.89 times lower, even on the basis of EBITDA:

$$
\frac{(-6,5)+(-3,5)+22,5+7,5}{22,5}=0,89
$$

"Berlik" may maintain a more significant decline in gross profit than "Search" before it ceases to receive sufficient cash to fully pay its interest expenses. This is due to the fact that depreciation expenses that reduce tax profit make up the majority of "Berlik's"total operating expenses $-4.2 \%$ of 447.5 million tenge compared to $1.9 \%$ of 390 million tenge for "Search" (table 1). It should also be noted that this difference indicates that "Berlik's" business is more capital-intensive than that of "Search".

Thus, this example shows that the traditionally measured fixed coverage is almost identical for both "Berlik" and "Search" companies, but they differ significantly in the probability of default for remuneration payments. This suggests that it is useful to calculate the fixed cost coverage coefficient in order to ensure comparability of companies with different depreciation policies when assessing the company's sustainability.

Further, we will confirm the results of several moreresearches that claim the need to calculate EBITDA to assess the sustainability of companies.

Fan, Thomas, and $\mathrm{Yu}$ (2019) investigated whether firms can whether firms with private loan contracts that contain debt covenants based on earnings before interest, taxes, 
depreciation, and amortization (EBITDA) are more likely to misclassify core expenses as special items (i.e., classification shift). Misclassifying core expenses as income-decreasing special items allows the firm to increase EBITDA and thereby potentially avoid debt covenant violations. Consistent with our expectation, firms misclassify core expenses as special items when at least one EBITDA-related financial covenant is close to being violated. In addition, classification shifting is more prominent when financially distressed firms are close to violating at least one EBITDA-related covenant. Whereas prior research on classification shifting focuses primarily on equity market incentives (e.g., meeting analysts' earnings forecasts), our study extends this research to private loan contracts to highlight that creditors also affect classification shifting. Classification shifting appears to be an additional earnings management technique used by managers to avoid debt covenant violations [13].

Jakasa (2017) searched the effect of EBITDA on creditworthiness based on an analysis of available and sustainable cash flow, taking into account that loans can be repaid exclusively with cash. Given that DSCR (Debt Service CoverageRatio) uses EBITDA as a proxy for available cash flow, the author focuses on the effect of EBITDA as a predictor variable. Jakasa assumes that one variable EBITDA margin, measured as EBITDA/revenue, has a significantly greater effecton the evaluation result than all the other variables considered, relying on its practical experience and proving with statistical methods based on a sample of 354 companies in Croatia. The model developed by the author has a forecast accuracy of $81.4 \%$, which confirms that the most influential variable is the EBITDA margin [14].

Cormier, Demaria, and Magnan (2017) searched whether formal disclosure of earnings before interest, taxes, depreciation, and amortization (EBITDA) reduces information asymmetry between managers and investors outside of GAAP earnings publication, and whether EBITDA disclosure increases the value of significance and predictive power of earnings. The methodology provides for the research of the interaction between GAAP and non-GAAP reporting, andthe impact of corporate governance on the quality of non-GAAP indicators. The results show that EBITDA reporting is associated with more analysts and less information asymmetry. The authors also argue that EBITDA reporting reinforces the positive interrelation between earnings and share prices, and also future cash flows. Moreover, according to the authors, corporate governance replaces EBITDA reporting for stock markets. Therefore, EBITDAsupports market participants better evaluate earnings when the firm's management is weak. Conversely, when management is strength, publishing EBITDA information has a much less impact on the earnings-to-share ratio [15].

\section{Conclusions}

The advantages of calculating EBITDA as an indicator of the company's sustainability are obvious. A business that has a large volume of capital expenditures wears unprofitable, "undermining" the stability of the economy of any country. However, calculating EBITDA, taking into account upfront costs, allowsus to show the company's sustainability more realistically. And enterprises that have a high share of depreciation and amortization costs for equipment and other long-term assets in their prime costs can firmly declare their sustainability. Because the assessment of a business's ability to pay off its liabilities and reinvest funds for future business development is based on EBITDA.

Moreover, as the example showed, EBITDA can identify the most stable company among enterprises that have an equal financial position at first glance.

Operating income tends to be more stable than expected earnings, gross profit before interest and taxes (EBIT) tends to be more stable than operating income, and EBITDA tends to be more stable than EBIT. 
Less volatile indicators confirm the company's stability, which is extremely important when evaluating a business.

A low level of net profit cannot reliably evidence the company's stability. Only operating incomes shows a complete picture of the financial stability of companies.

In this regard, when assessing the sustainability of companies, financial analysts must research many measures to get maximum information to identify the real picture of the company's sustainability.

\section{References}

1. T. Mukhambetov, F.Yerdavletova, ICMLG (2014)

2. J. Wahlen, S. Baginski, M. Bradshaw, Financial Reporting, Financial Statement Analysis, and Valuation: A Strategic Perspective (2015)

3. E. Lie, H.J. Lie, Financial analysts Journal, 58(2) (2002)

4. R. Oliveira, J.Felipe, V.Junior, D. Baiardo, R.Ponte, V. Maria, M. Domingos, S. Rejane, Revista Ambiente Contabil, 9(2) (2017)

5. A. J. Pereira, L. Lucena, W. Glaucio, Sistemas\&Gestao, 12(2) (2017)

6. S. S. Ahmed, Global business review, 16(5) (2015).

7. C.-Serrano, B.-Contell, L.-Serer, R.-M. Andrea, Journal of business research, 89 (2018)

8. J. P. Damijan, Post-communist economies, 30(2) (2018)

9. De Carvalho, A. Oliveira, R. Ivano, S. Cirani, C. Brito, C. R. Fabiano, International Journal of innovation, 4(1) (2016)

10. P. F. Kaznacheev, N.V. Kjurchiski, R.V. Samoilova, Economic policy, 12(6) (2017)

11. J. Janekova, J.Fabianova, D. Onofrejova, E. Puskas, M. Busa, Polish Journal of management studies, 15(1) (2017)

12. F. Yerdavletova, B. Ermekbaeva, G. Zhunissova, Zh. Mukhametzhanova, E3S Web of Conferences, 159 (2020)

13. Y. Fan, W.B. Thomas, X. Yu, Management science, 65(8) (2019)

14. P. Jakasa, 26th International Scientific Conference on Economic and Social Development (2017)

15. D. Cormier, S. Demaria, M. Magnan, Managerial finance, 43(2) (2017) 